\title{
Nitrogen limitation of chemostat-grown Rhizobium et/i elicits higher infection-thread formation in Phaseolus vulgaris
}

\author{
Graciela Brelles-Mariñoł and José L. Boiardi \\ Author for correspondence: G. Brelles-Mariño. Tel: +54 21250497. \\ e-mail: brelles@biol.unlp.edu.ar
}

Centro de Investigación y

Desarrollo en

Fermentaciones

Industriales (CINDEFI),

Facultad de Ciencias

Exactas, Universidad

Nacional de La Plata, calles

47 y 115, 1900-La Plata,

Argentina

\begin{abstract}
The symbiotic association between rhizobia and legume roots is a complex process involving many steps. An infection thread is a tubular structure of host origin formed during the infection of legume roots by rhizobia. Previous studies with batch cultures have reported that optimal attachment of rhizobia to root hairs coincides with nutrient limitation. In this study, the ability of chemostat-grown, nutrient-limited Rhizobium etli cells to form infection threads with its symbiotic partner Phaseolus vulgaris was investigated. Rhizobia were grown in a chemostat in synthetic media under $\mathbf{C}$ - or $\mathbf{N}$-limiting conditions. Infection-thread formation was examined after inoculation of seedlings with a rhizobial cell suspension from each treatment. The number of infection threads was estimated by light microscopy after staining root sections with o-toluidine. Exopolysaccharide (EPS) production was also measured, and the cellular content and electrophoretic pattern of lipopolysaccharide (LPS) determined semiquantitatively. $\mathbf{N}$-limited cells showed a markedly higher infectivity (measured as infection-thread formation) than C-limited cells. With one of the two bean cultivars used, the number of infection threads produced by $\mathbf{N}$-limited cells was higher than that produced by exponentially growing cells in batch cultures. The higher infectivity of $\mathbf{N}$-limited cells was correlated with higher EPS production. Electrophoretic analysis of LPS showed that $\mathrm{C}$ - and $\mathrm{N}$-limited cells shared a common profile but the relative concentration of short LPS forms differed.
\end{abstract}

Keywords: Rhizobium etli, plant-microbe interactions, infection threads, Pbaseolus vulgaris, nitrogen limitation

\section{INTRODUCTION}

The symbiotic association between rhizobia and legume roots is a multistep process initiated by preinfection events in the rhizosphere. The plant and the bacteria exchange specific signals before infection. Infective thizobia recognize and attach to the region of the rhizoplane that is most susceptible to infection, the site of emerging root hairs. Root hairs become curled and entrap bacterial cells in a pocket of host cell wall material. Rhizobia enter the roots at sites where the root hair cell walls are

This paper is dedicated to the memory of Lara Schroder

† Present address: Instituto de Bioquímica y Biología Molecular, Facultad de Ciencias Exactas, Universidad Nacional de La Plata, calles 47 y 115, 1900La Plata, Argentina.

Abbreviation: EPS, exopolysaccharide. hydrolysed and induce the formation of a tubular structure of host origin called the 'infection thread' (van Rhijn \& Vanderleyden, 1995). There are several reports on roothair deforming and curling substances and infectionthread promoting factors (Abe et al., 1982; Dazzo et al., 1991; Higashi \& Abe, 1980; Lugtenberg et al., 1991). In the Rhizobium etli-Phaseolus vulgaris association we previously demonstrated that legume lectin enhances infection-thread formation (Brelles-Mariño et al., 1993, 1996). This effect was also reported by Lodeiro \& Favelukes (1995) with soybean lectin and Bradyrbizobium japonicum.

Smit et al. (1986, 1987, 1989a, b, 1991) and Kijne et al. (1988) studied the attachment capacity of Rhizobium leguminosarum biovar viciae to pea root hairs under various physiological conditions. They concluded that the conditions under which rhizobia are grown strongly influence 
their ability to attach to root hairs, and that nutrient limitation always coincides with optimal attachment. Climited R. leguminosarum biovar viciae cells did not induce infection-thread formation, while $\mathrm{Mn}^{2+}$-limited cells yielded the highest number of infection threads (Kijne et al., 1988).

However, the above studies were all carried out with batch cultures and, as demonstrated by Pronk et al. (1995), growth in batch cultures can be very different from growth in continuous culture. These authors advised against drawing conclusions on the basis of batch cultures only. The use of a chemostat facilitates study of the response of the organism to its environment. In a batch culture, substrate-limited growth can be obtained only transiently, but in continuous culture it is possible to obtain substrate-limited growth with a constant growth rate.

In the soil and rhizosphere, bacteria are subject to changing environmental conditions including nutritional stresses such as $\mathrm{C}, \mathrm{N}$ and $\mathrm{O}_{2}$ limitation (de Bruijn et al., 1995). The use of a chemostat and a synthetic medium allowed us to test the effect of some of these conditions on the Rbizobium-legume symbiosis. In the study reported here, we investigated the ability of nutrient-limited cells of R. etli to form infection threads within its symbiotic partner, P. vulgaris.

\section{METHODS}

Plant varieties. Seeds from two Phaseolus vulgaris cultivars were used: Alubia (white bean) and Bat 76 (black bean). Both were obtained from INTA (Instituto Nacional de Tecnología Agropecuaria), Cerrillos, Argentina.

Bacterial strain and culture conditons. Rhizobium etli strain F48 (obtained from INTA, Castelar, Argentina), able to nodulate $P$. vulgaris, was used. Bacteria were maintained on slants consisting of solidified Götz medium (Götz et al., 1982). This medium contained the following components $\left(\mathrm{g} \mathrm{l}^{-1}\right)$ : mannitol, $10 \cdot 0 ;\left(\mathrm{NH}_{4}\right)_{2} \mathrm{SO}_{4}, 0.13 ; \mathrm{K}_{2} \mathrm{HPO}_{4}, 1.06 ; \mathrm{KH}_{2} \mathrm{PO}_{4}$, $0.52 ; \mathrm{MgSO}_{4} .7 \mathrm{H}_{2} \mathrm{O}, 0.25 ; \mathrm{CaCl}_{2}, 0.011 ; \mathrm{NaCl}, 0.006$; $\mathrm{Na}_{2} \mathrm{MoO}_{4}, 0.002$. Micronutrient components $\left(\mu \mathrm{g} \mathrm{ml}^{-1}\right)$ were: $\mathrm{FeSO}_{4}, 150$; riboflavin, 20; $p$-aminobenzoic acid, 20; pyridoxine. $\mathrm{HCl}, 20$; thiamin. $\mathrm{HCl}, 20$; biotin, 20 .

Bacteria from slants were grown at $30^{\circ} \mathrm{C}$ in $250 \mathrm{ml}$ Erlenmeyer flasks containing $50 \mathrm{ml}$ Götz medium with vigorous aeration (200 r.p.m. incubator shaker, New Brunswick Scientific).

The synthethic medium for the C-limited chemostat cultures contained $\left(\mathrm{g} \mathrm{l}^{-1}\right)$ : mannitol, $2 \cdot 00 ;\left(\mathrm{NH}_{4}\right)_{2} \mathrm{SO}_{4}, 2 \cdot 60 ; \mathrm{KH}_{2} \mathrm{PO}_{4}$, $0.71 ; \mathrm{MgSO}_{4} .7 \mathrm{H}_{2} \mathrm{O}, 0.25$. The other components of Götz medium were added in the same quantities given above, except that no $\mathrm{K}_{2} \mathrm{HPO}_{4}$ was used. The synthetic medium for the Nlimited chemostat cultures contained $\left(\mathrm{g} \mathrm{l}^{-1}\right)$ : mannitol, $10 \cdot 0$; $\left(\mathrm{NH}_{4}\right)_{2} \mathrm{SO}_{4}, 0.52$ and the other components of Götz medium as indicated above. In both nutrient-limited chemostat cultures $\mathrm{MnSO}_{4} \cdot 4 \mathrm{H}_{2} \mathrm{O}$ was also added to obtain a final concentration of $1 \cdot 0 \mu \mathrm{M}$. This concentration was chosen because it has been demonstrated that rhizobial growth is maximal with $1.0 \mu \mathrm{M}$ $\mathrm{Mn}^{2+}$ (Wilson \& Reisenauer, 1970).

Media were autoclaved in 81 batches for $45 \mathrm{~min}$. The stock solution of micronutrients was sterilized by filtration through a $0.2 \mu \mathrm{m}$ pore size membrane and aliquots were stored frozen.
Synthetic media were supplemented with $1 \mathrm{ml}$ micronutrient solution $1^{-1}$ before inoculation.

Chemostat culture experiments. These were carried out in laboratory chemostats (LKB Bromma 1001 Ultroferm or New Brunswick BioFlo $\mathrm{C} 30 ; 2.5$ or 0.41 volume, respectively) at $30{ }^{\circ} \mathrm{C}$. The aeration rates were $8-10$ and $11.5-16.51 \mathrm{~h}^{-1}$, respectively. The medium flow was regulated to obtain a dilution rate $(D)$ of $0.03 \pm 10 \% \mathrm{~h}^{-1}$. Foam formation was prevented by the automatic addition of an antifoaming agent and $\mathrm{pH}$ was maintained at a value of $6.95 \pm 0.15$ by the automatic additon of $\mathrm{NaOH}$ or $\mathrm{H}_{2} \mathrm{SO}_{4}$.

Analytical methods. These were performed once the culture reached steady state conditions (after at least 10-15 retention times). Samples $(10 \mathrm{ml})$ were centrifuged at $6000 \mathrm{~g}$ for $10 \mathrm{~min}$. Pellets were washed twice with distilled water and dried at $105^{\circ} \mathrm{C}$ until constant weight was attained. Bacterial concentration was measured as dry wt $(1 \text { culture })^{-1}$. Supernatants were separated and stored at $-20^{\circ} \mathrm{C}$ to determine exopolysaccharide (EPS), mannitol and $\mathrm{NH}_{4}^{+}$. EPS was determined colorimetrically with anthrone (Herbert et al., 1971). Mannitol and $\mathrm{NH}_{4}^{+}$were determined colorimetrically according to Lambert \& Neisch (1950) and Chaney \& Marbach (1962), respectively. Culture samples containing approximately the same biomass concentration were centrifuged and pellets used to compare lipopolysaccharide (LPS) content of cells grown under $\mathrm{C}$ or $\mathrm{N}$ limitation. LPS were extracted by using $100 \mathrm{mM}$ EDTA, pH 7.0 (C. Valverde, D. Hozbor \& A. Lagares, unpublished). Samples were separated in SDS-PAGE gels and silver-stained as described by 'Tsai \& Frash (1982).

Infection thread assay. Infection-thread formation was studied after inoculation of $P$. vulgaris seedlings with suspensions of $1 \times 10^{7}$ cells $\mathrm{ml}^{-1}$. The infection-thread assay was performed with secondary roots of bean plants growing in plastic growth pouches. The number of infection threads was estimated by microscopy after staining the root sections with $o$-toluidine (Pueppke, 1983). Uninoculated seedlings were used as controls. All assays with seedlings were performed under microbiologically controlled conditions. Samples were taken 8 and $14 \mathrm{~d}$ after inoculation.

\section{RESULTS AND DISCUSSION}

The number of infection threads per root produced by $R$. etli grown in continuous culture under different substrate limitations was determined. Plants were scored 8 and $14 \mathrm{~d}$ after inoculation, but no significant differences occurred between the two sampling dates (data not shown). We evaluated infection threads mainly in pre-existing root hairs but, because of the fibrous morphology of bean roots (Graham \& Halliday, 1977), some roots developed after inoculation could also be excised. The anatomical nature of the bean root did not allow us to use the method of Bhuvaneswari et al. (1981) in which soybean and alfalfa roots formed before and after inoculation were clearly distinguished by marking the root tip at the time of inoculation.

There are very few studies relating thizobial nutrient limitation with preinfection and infection processes in legumes. As far as we know, only Smit et al. (1986, 1987, 1989a, b, 1991) and Kijne $e t$ al. (1988) have reported data on infection-thread formation in $R$. leguminosarum biovar viciae. Many of these results were obtained with batch cultures which, as indicated above, are not an appropriate 


\section{Table 1. Infectivity of $R$. etli F48 grown under different nutrient limitations}

$P$. vulgaris seeds were pregerminated in petri dishes and transferred aseptically to plastic pouches. Each

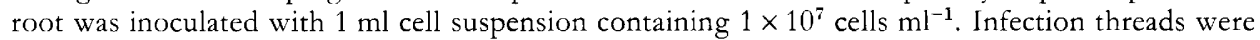
counted $8 \mathrm{~d}$ after inoculation. Data are the average of at least 5 roots and were analysed by the Student's $t$-test. Values obtained from $\mathrm{C}$ - and $\mathrm{N}$-limited chemostat cultures are highly significantly different $(P<0 \cdot 01)$. Results are the average of four independent experiments.

\begin{tabular}{|lcc|}
\hline Growth conditions & \multicolumn{2}{l|}{ No. infection threads per $P$. vulgaris root } \\
\cline { 2 - 3 } & Cv. Alubia & Cv. Bat 76 \\
\hline Chemostat culture, C-limited & $2 \cdot 5$ & $2 \cdot 2$ \\
Chemostat culture, N-limited & $16 \cdot 0$ & $7 \cdot 5$ \\
Batch culture, exponential phase & $7 \cdot 8$ & $4 \cdot 5$ \\
\hline
\end{tabular}

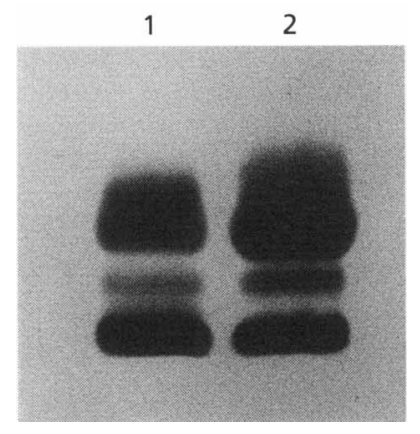

Fig. 1. LPS profile of $\mathrm{N}$-limited (lane 1) and C-limited (lane 2) $R$. et $/ i$ F48 cells after SDS-PAGE $(15 \%, w / v$, acrylamide) visualized by silver-staining. LPS was extracted and determined as given in Methods.

system for this type of physiological experiment. Lower infectivity of cells from C-limited cultures was reported for R. leguminosarum biovar viciae (Smit et al., 1986, 1987). In this case, the authors used cells that had been grown in a complex medium in which they reported $\mathrm{C}$ as the growth-limiting nutrient. To verify that the substrate was actually limiting growth, we measured the concentration of the limiting nutrient under steady-state conditions. Mannitol and $\mathrm{NH}_{4}^{+}$were undetectable in the supernatants from $\mathrm{C}$ - or $\mathrm{N}$-limited cultures, respectively. Moreover, we measured bacterial growth (cell count and cell dry wt) after pulses of each nutrient-limiting substrate. C-limited cultures responded to the addition of mannitol and $\mathrm{N}$ limited cultures to the addition of ammonium sulfate by increasing biomass concentration immediately after nutrient addition (data not shown).

There was a marked difference in infectivity (measured as number of infection threads) between $\mathrm{C}$-limited and $\mathrm{N}$ limited cells (Table 1). N-limited cells were much more infective than cells under $\mathrm{C}$ limitation. In cultivar Alubia, the number of infection threads was even higher than that obtained with exponentially growing cells in batch cultures. It has been reported that cells obtained from the exponential growth phase in batch culture are the most infective population (Boiardi \& Galar, 1988). The higher infectivity of $\mathrm{N}$-limited cells relative to $\mathrm{C}$-limited ones was correlated with differences in EPS production. EPS yield under $\mathrm{N}$ - and C-limited conditions was 115 and $6.4 \mathrm{mg}$ EPS ( $\mathrm{g}$ biomass) ${ }^{-1}$, respectively. However, nutrient limitation appeared to alter the relative intensity (as judged by silver-staining) of short LPS forms without a noticeable band profile modification (Fig. 1).

Some of the initial stages of nodulation are believed to involve EPS and LPS but the actual role of these polysaccharides in the nodulation process is not clear. Although EPS is not essential for attachment (Bauer, 1981), it stimulates the process and might also facilitate the infection of legumes by rhizobia. Yang et al. (1992) found that R. meliloti exo mutants (EPS ${ }^{-}$) were not able to form complete infection threads. Kijne et al. (1988) proposed that $\mathrm{C}$-limited rhizobia are not infective at the time of inoculation because of the lack of lectin receptor molecules and/or the lack of EPS on the rhizobial surface. The correlation between EPS production and infectionthread formation found in our study is consistent with the above hypothesis. It can be speculated that the enhanced infectivity obtained with $\mathrm{N}$-limited rhizobia could be explained by an appropriate concentration of EPS on the bacterial surfaces. Carlson et al. (1987) tentatively suggested that the ability to synthesize LPS molecules containing the $\mathrm{O}$-antigen is essential for initial stages of infection. Cava et al. (1989) demonstrated that complete LPS structures, in normal amounts, are necessary for infection-thread development in bean plants. Changes in the relative concentration of LPS forms were correlated with nutrient limitations (Fig. 1), therefore enhanced infectivity of N-limited cells might also be attributed to differences in the composition of this polysaccharide. However, futher research is required to determine whether EPS and/or LPS (or neither) are responsible for the enhanced infectivity of N-limited thizobia.

Our study correlated rhizobial infectivity with different growing conditions and showed the potential of chemostat culture as a tool for studying the effects of different limiting substrates on the symbiotic competence of rhizobia. The rhizosphere environment is quite different from the conditions under which rhizobia are classically grown in the laboratory and the chemostat allowed us to approximate some of the conditions under which the 
micro-organisms proliferate and infect the host plant in the soil.

\section{ACKNOWLEDGEMENTS}

This work was supported in part by a grant from the Commission of the European Communities (contract CI1* CT91-0914). We thank Claudio Valverde for running the LPS gels and Guillermo Costa for performing the infection-thread assays. J. L. Boiardi is a research member of CONICET (Argentinean Research Council).

\section{REFERENCES}

Abe, M., Anemura, A. \& Higashi, S. (1982). Studies on cyclic beta1,2 glucan obtained from the periplasmic space of Rbizobium trifolii cells. Plant Soil 64, 315-324.

Bauer, W. D. (1981). Infections of legumes by rhizobia. Ann Rev Plant Pbysiol 32, 407-449.

Bhuvaneswari, T. V., Bhagwat, A. A. \& Bauer, W. D. (1981). Transient susceptibility of root cells in four common legumes to nodulation by Rbizobia. Plant Pbysiol 68, 1144-1149.

Boiardi, J. L. \& Galar, M. L. (1988). Nodulation of Phaseolus vulgaris L. as affected by Rhizobium phaseoli growth phase. Can J Microbiol 34, 63-67.

Brelles-Mariño, G., Costa, G. A. \& Boiardi, J. L. (1993). Pretreatment of $R$. phaseoli with $P$. vulgaris seed lectin promotes infection thread formation. In New Horizons in Nitrogen Fixation, $\mathrm{p}$. 330. Edited by R. Palacios, J. Mora \& W. E. Newton. Dordrecht: Kluwer.

Brelles-Mariño, G., Costa, G. A. \& Boiardi, J. L. (1996). Enhancement of infection thread formation by Rhizobium etli incubated with bean seed lectin. Microbiol Res 151, 1-4.

de Bruijn, F. J., Graham, L., Milcamps, A. \& Ragatz, D. (1995). Use of luciferase (Tn5-lux) reporter system to study Rbizobium meliloti genes responding to $\mathrm{N}, \mathrm{C}$ and $\mathrm{O}_{2}$ limitation or plant factors and their role in rhizosphere competition. In 10th International Congress on Nitrogen Fixation, Abstract 25S. St Petersburg, Russia.

Carlson, R. W., Kalembasa, S., Turkowski, D., Pahori, P. \& Noel, K. D. (1987). Characterization of the lipopolysaccharide from a Rbizobium phaseoli mutant that is defective in infection thread development. J Bacteriol 169, 4923-4928.

Cava, J. R., Elias, P. M., Turowski, D. A. \& Noel, K. D. (1989). Rhizobium leguminosarum CFN42 genetic regions encoding lipopolysaccharide structures essential for complete nodule development on bean plants. $J$ Bacteriol 171, 8-15.

Chaney, A. L. \& Marbach, E. P. (1962). Modified reagents for determination of urea and ammonia. Clin Chem 8, 130-132.

Dazzo, F. B., Truchet, G. L., Hollingsworth, R. I., Hrabak, E. M., Pankratz, H. S., Philip-Hollingsworth, S., Salzwedel, J. L., Chapman, K., Appenzeller, L., Squartini, A., Gerhold, D. \& Orgambide, G. (1991). Rhizobium polysaccharide modulates infection thread development in white clover root hairs. J Bacteriol 173, 5371-5384.

Graham, P. H. \& Halliday, J. (1977). Inoculation and nitrogen fixation in the genus Phaseolus. In Exploiting the Legume-Rbizobium Symbiosis in Tropical Agriculture, p. 313. Edited by J. M. Vincent, A. S. Whitney \& J. Bose. Honolulu: College of Tropical Agriculture, University of Hawai.

Götz, R., Limmer, N., Ober, K. \& Schmitt, R. (1982). Motility and chemotaxis in two strains of Rbizobium with complex flagella. J Gen Microbiol 128, 789-798

Herbert, D., Phipps, P. J. \& Strange, R. E. (1971). Chemical analysis of microbial cells. Methods Microbiol 5B, 265-272.
Higashi, S. \& Abe, M. (1980). Promotion of infection thread formation by substances from Rbizobium. Appl Environ Microbiol 39, 753-760.

Kijne, J. W., Smit, G., Diaz, C. L. \& Lugtenberg, B. J. J. (1988). Lectin-enhanced accumulation of manganese-limited Rhirobium leguminosarum cells on pea root hair tips. J Bacteriol 170, 2994-3000. Lambert, M. \& Neisch, A. C. (1950). Rapid method for estimation of glycerol in fermentation solutions. Can J Res 28, 83-89.

Lodeiro, A. R. \& Favelukes, G. (1995). Enhanced adsortion to soybean roots, infectivity and competition for nodulation of Bradyrbizobium japonicum pretreated with soybean lectin. In 10th International Congress on Nitrogen Fixation, Abstract 213. St Petersburg, Russia.

Lugtenberg, B. J. J., Diaz, C. L., Smit, G., de Pater, S. \& Kijne, J. W. (1991). Roles of lectin in the Rbizobium-legume symbiosis. In Advances in Molecular Genetics of Plant-Microbe Interactions, vol. I, pp. 174-181. Edited by H. Hennecke \& D. P. S. Verma. Dordrecht: Kluwer.

Pronk, A. F., Stouthamer, A. H., van Verseveld, H. W. \& Boogerd, F. C. (1995). Nicotinate catabolism is dispensable and nicotinate anabolism is crucial in Azorbizobium caulinodans growing in batch culture and chemostat culture on $\mathrm{N}_{2}$ as the $\mathrm{N}$ source. J Bacterio/177, 75-81.

Pueppke, S. G. (1983). Rhizobium infection threads in root hairs of Glycine $\max (\mathrm{L})$. Merr, Glycine soja Sieb and Zucc, and Vigna unguiculata (L). Walp. Can J Microbiol 29, 69-76.

van Rhijn, P. \& Vanderleyden, J. (1995). The Rhizobium-plant symbiosis. Microbiol Rev 59, 124-142.

Smit, G., Kijne, J. W. \& Lugtenberg, B. J. J. (1986). Correlation between extracellular fibrils and attachment of Rhizobium leguminosarum to pea root hair tips. J Bacteriol 168, 821-827.

Smit, G., Kijne, J. W. \& Lugtenberg, B. J. J. (1987). Involvement of both cellulose fibrils and $\mathrm{Ca}^{2+}$-dependent adhesin in the attachment of Rbizobium leguminosarum to pea root hair tips. J Bacteriol 169 , 4294-4301.

Smit, G., Kijne, J. W. \& Lugtenberg, B. J. J. (1989a). Roles of flagella, lipopolysaccharide and a $\mathrm{Ca}^{2+}$-dependent cell surface protein in attachment of Rhizobium leguminosarum biovar viciae to pea root hair tips. J Bacteriol 171, 569-572.

Smit, G., Logman, T. J. J., Boerrigter, M. E. T. I., Kijne, J. W. \& Lugtenberg, B. J. J. (1989b). Purification and partial characterization of the Rbizobium leguminosarum biovar viciae $\mathrm{Ca}^{2+}$ dependent adhesin, which mediates the first step in attachment of cells of the family Rbizobiaceae to plant root hair tips. J Bacteriol 171 4054-4062.

Smit, G., Tubbing, D. M. J., Kijne, J. W. \& Lugtenberg, B. J. J. (1991). Role of $\mathrm{Ca}^{2+}$ in the activity of rhicadhesin from Rhizobium leguminosarum biovar viciae, which mediates the first step in attachment of Rhizobiaceae to plant root hair tips. Arch Microbiol $155,278-283$.

Tsai, C.-M. \& Frash, C. E. (1982). A sensitive silver stain for detecting lipopolysaccharide in polyacrylamide gels. Anal Biochem 119, 115-119.

Wilson, D. O. \& Reisenauer, H. M. (1970). Effect of manganese and zinc ions on the growth of rhizobia. J Bacteriol 102, 729-732.

Yang, C., Signer, E. R. \& Hirsch, A. M. (1992). Nodules initiated by Rhizobium meliloti exopolysaccharide mutants lack a discrete, persistent nodule meristem. Plant Pbysiol 98, 143-151.

Received 1 September 1995; revised 14 December 1995; accepted 2 January 1996. 